\title{
A zero-exposure time test on an erratic boulder: evaluating the problem of pre-exposure in surface exposure dating
}

\author{
Luca M. Abbühl, Naki Akçar, Stefan Strasky, Angela A. Graf, \\ Susan Ivy-Ochs \& Christian SchlÜChter ${ }^{*}$
}

\begin{abstract}
The method of surface exposure dating using in-situ produced cosmogenic nuclides has become an important and widely applied tool in Quaternary science. One application is the dating of erratic boulders on moraines. An important problem however remains: the evaluation of potential pre-exposure time for samples from boulder surfaces. We have tested pre-exposure by sampling all sides of a recently exposed boulder in order to measure inherited nuclides from prior exposure periods. The sampled erratic boulder rests on the right lateral moraine of the most recent advance of the Glacier de Tsijiore Nouve in the Arolla Valley, Switzerland. Mapping of the area was done to reconstruct the Holocene fluctuations of the glacier. This glacier is especially useful for such a test as it is characterized by an ideal geometric relationship between accumulation and ablation area and, therefore, responds rapidly to mass-balance changes. The sampled boulder was deposited in 1991. Assuming no prior exposure the expected concentration of a given cosmogenic nuclide should be near zero. The ${ }^{10} \mathrm{Be} /{ }^{9} \mathrm{Be}$ ratios of the five measured samples were indistinguishable from blank values within the given errors, demonstrating that the samples did not experience pre-exposure. Three samples measured for ${ }^{21} \mathrm{Ne}$ reveal ${ }^{21} \mathrm{Ne} /{ }^{20} \mathrm{Ne}$ and ${ }^{22} \mathrm{Ne} /{ }^{20} \mathrm{Ne}$ ratios similar to those of air, with no detectable prior cosmogenic $\mathrm{Ne}$ accumulation.
\end{abstract}

[Ein Experiment an einem 1991 abgelagerten erratischen Block: Annäherung an das Problem der Vorbestrahlung in der Oberflächendatierung]

Kurzfassung: Die Oberflächendatierung mittels in-situ produzierten kosmogenen Nukliden hat sich in den letzten Jahren in der Quartärgeologie zu einer wichtigen und häufig angewandten Methode entwickelt. Eine Anwendung ist die Altersbestimmung von erratischen Blöcken auf Moränen. Ein wesentliches Problem ist jedoch die Ermittlung einer eventuellen vorherigen Bestrahlungsperiode eines Blockes. Wir haben dies getestet, indem wir alle Seiten eines kürzlich exponierten Blockes beprobten und die Proben auf schon vorhandene Nuklide hin untersuchten. Der untersuchte Block liegt auf der rechten lateralen Moräne des jüngsten Gletschervorstosses des Glacier de Tsijiore Nouve im Val d'Arolla in der Schweiz. Die holozänen Gletscherschwankungen wurden durch eine Kartierung rekonstruiert. Durch die ideale geometrische Verteilung von Akkumulations- und Ablationsgebiet reagiert dieser Gletscher schnell auf Änderungen der Massenbilanz. Daher ist er besonders gut für einen solchen Test geeignet. Der beprobte Block wurde 1991 durch den Gletscher abgelagert. Durch die Annahme, dass er vorher keiner kosmogenen Strahlung ausgesetzt war, sollte seine Nuklidkonzentration annähernd null sein. Die gemessenen ${ }^{10} \mathrm{Be} /{ }^{9} \mathrm{Be}$ Verhältnisse der fünf Proben waren innerhalb der Fehler nicht zu unterscheiden von Blindprobenwerten. Dies zeigt, dass die Proben keiner Vorbestrahlung ausgesetzt waren. Gemessene ${ }^{21} \mathrm{Ne} /{ }^{20} \mathrm{Ne}$ und ${ }^{22} \mathrm{Ne} /{ }^{20} \mathrm{Ne}$ Verhältnisse bei drei Proben sind ähnlich derer in der Luft, mit keiner nachweisbaren vorhergehenden kosmogenen Ne Anreicherung.

Keywords: Surface exposure dating, pre-exposure, Swiss Alps

* Addresses of authors: L. M. Abbühl, N. Akçar, A. A. Graf, C. Schlüchter, University of Bern, Institute of Geological Sciences, Baltzerstr. 1+3, 3012 Bern, Switzerland. E-Mail: luca@geo.unibe.ch; S. Strasky, ETH Zurich, Department of Earth Sciences, Sonneggstr. 5, 8092 Zurich, Switzerland; S. Ivy-Ochs, ETH Zurich, Institute of Particle Physics, 8093 Zurich, Switzerland. 


\section{Introduction}

The method of surface exposure dating has become a useful and widespread tool in Quaternary science (for a review of the method see Gosse \& Phillips 2001). Surface exposure dating has been most extensively applied to studies directly dating the advance of a glacier from boulders on moraine ridges. By measuring the nuclide concentration resulting from reactions of cosmic ray particles with target elements in the rock surfaces, a surface's exposure and, therefore, resting time can be determined. Estimating the correct exposure age, however, also requires knowledge of previous surface exposure histories. There are many possible scenarios for a rock to have been exposed prior to reaching its present position, e.g., in a cliff before falling onto the glacier or in an older moraine ridge which became reworked by a more recent advance (BRown et al. 1991, BRoOK et al. 1995). The eventual case of inherited nuclides from prior exposure is usually neglected in the application of surface exposure dating and therefore the estimated ages may be incorrect.

The goal of this study is to examine the exposure time of each side of a specific boulder of known, very young exposure age. If the samples have no prior exposure history, then concentrations of cosmogenic nuclides should be very low or even undetectable as the exposure time is too short to build up a significant amount of nuclides. To cross-check the possibility of a long-term prior exposure followed by a significant shielding period, we estimated the concentrations of the cosmogenic nuclides ${ }^{10} \mathrm{Be}$ and ${ }^{21} \mathrm{Ne}$. While the unstable ${ }^{10} \mathrm{Be}$ decays during times of burial, the stable cosmogenic ${ }^{21} \mathrm{Ne}$ records the total accumulated exposure time. Thus, the comparison of ${ }^{21} \mathrm{Ne}$ to ${ }^{10} \mathrm{Be}$ is suitable for detecting pre-exposure of the surface by revealing a higher ${ }^{21} \mathrm{Ne}$ concentration than expected compared to the ${ }^{10}$ Be concentration (GRAF et al. 1991).

We sampled a boulder resting on the right lateral moraine crest of the maximum stand of the most recent advance (1975-1991) of the debrisrich Glacier de Tsijiore Nouve near Arolla, in the uppermost part of the Val d'Hérens in the south-western Swiss Alps (Fig. 1). All sides of the boulder were sampled in order to test for possible pre-exposure for all possible past orientations of the boulder (Fig. 2). The boulder was identified during careful geological mapping of the Holocene fluctuations of the glacier (АввÜHL et al. 2002). It is very suitable due to its enormous size, its stable position since deposition and its known deposition age (1991). The Glacier de Tsijiore Nouve has ideal characteristics for this test as it reacts rapidly to mass balance changes due to its relatively small extent (and therefore short transport distance of the debris) and to its geometry of accumulation to ablation area.

This case study is the first to test pre-exposure in a high Alpine setting by estimating the concentrations of cosmogenic nuclides $\left({ }^{10} \mathrm{Be}\right.$ and ${ }^{21} \mathrm{Ne}$ ) in different faces of an individual boulder. It is a contribution to the question as to whether it is possible to rule out pre-exposure of boulder surfaces whenever sampling boulders of unknown age.

\section{Overall setting}

The uppermost part of the Val d'Hérens, the Val d'Arolla, is characterized by an open basin and steep valley walls. The village of Arolla, situated on the valley floor, has an altitude of $2000 \mathrm{~m}$ a.s.l. and the highest of the surrounding mountains, the Pigne d'Arolla, reaches 3796 m a.s.l. A relatively steep east and a more open west valley wall terminate the valley. Three glaciers terminate in close distance to Arolla, namely the Glacier de Tsijiore Nouve, the Glacier de Pièce and the Glacier d'Arolla. The Glacier d'Arolla is the main valley glacier while the others meet the valley of Arolla at approximately $90^{\circ}$. Well-defined moraines of glacial advances since the last glaciation cover the area (Fig. 1). In particular the Glacier de Tsijiore Nouve has accumulated moraine ridges of up to $80 \mathrm{~m}$ height because of its reduced sediment transfer. Its most extensive, still identifiable, Holocene advance is dated to $8400 \pm 200{ }^{14} \mathrm{C}$ yr BP (e.g. moraines at Hôtel Kurhaus in Fig. 1 (Schneebeli \& Röthlisberger 1976)) while the 


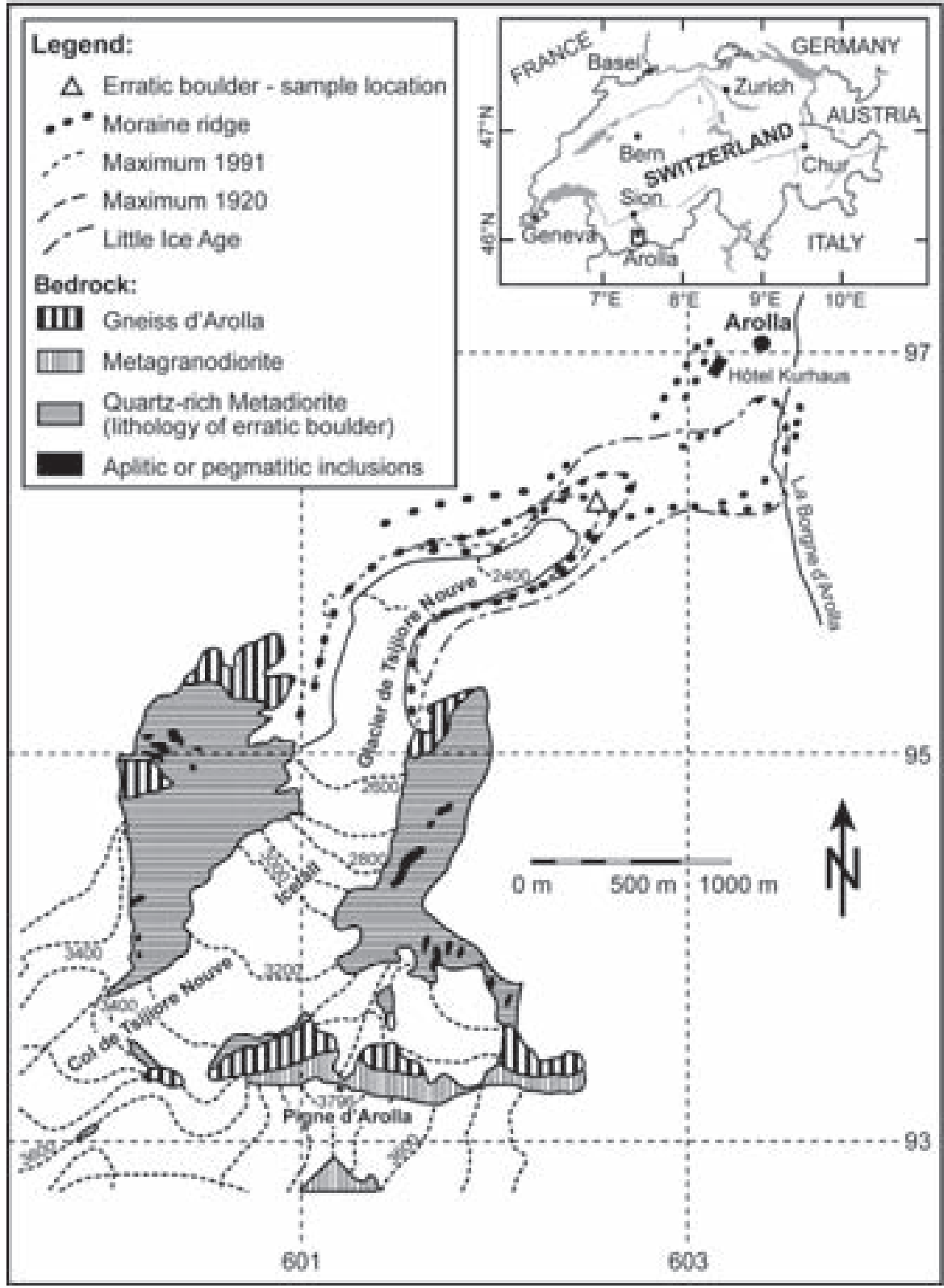

Fig. 1: Location of the study area (inset in map of Switzerland): Schematic map of the fluctuations of the Glacier de Tsijiore Nouve with the geological units in the catchment area. The moraine locations are based on detailed geological mapping during the summer of 2002 (АввÜHL et al. 2002), while the geological units are drawn after BURRI et al. (1999).

Abb. 1: Lage des Untersuchungsgebietes (Rechteck in der Übersichtskarte der Schweiz): Schematische Zeichnung der Schwankungen des Glacier de Tsijiore Nouve und der in seinem Einzugsgebiet anstehenden geologischen Einheiten. Die Schwankungen (dargestellt durch die Moränen) wurden im Sommer 2002 kartiert (АввÜHL et al. 2002), während die geologischen Einheiten nach BURRI et al. (1999) übernommen wurden. 


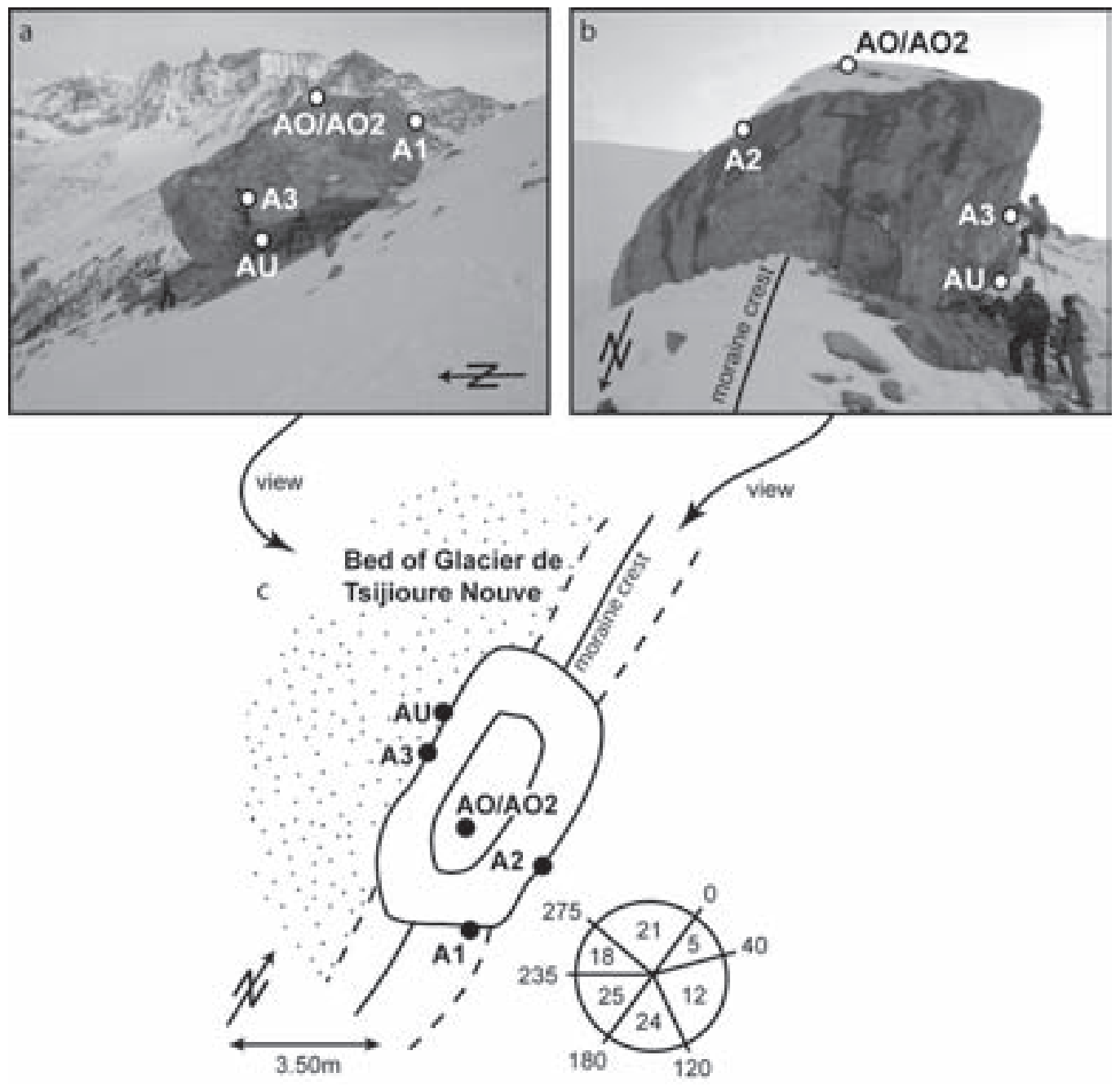

Fig. 2: Photographs and a figure of the boulder deposited on the moraine crest with a side (a), an upvalley (b) and a plane view (c). The white and black circles indicate the exact sampling locations. Note the overhanging part at the base of the glacier-facing side of the boulder where a shielded bottom sample could be taken (sample AU). The circle is a scheme for the shielding of the boulder by the surrounding mountains, measured with an inclinometer. Zero equals north and the numbers in the circle are the shielding values for the particular azimuth segments in degrees. The open valley is reflected by the low shielding values to the north-northeast. The shielding factor calculated after Dunne, Elmore \& Muzikar (1999) is presented in Tab. 2.

Abb. 2: Aufnahmen ((a) seitlich und (b) talaufwärts) und eine Figur ((c) von oben) des auf dem Moränenwall abgelagerten Blockes. Die weißen und schwarzen Kreise markieren die exakten Probenlokalitäten. Eine von Bestrahlung abgeschirmte Probe konnte unter dem überhängenden Teil des Blockes auf dessen dem Gletscherbett zugewandten Seite entnommen werden (Probe AU). Der Kreis ist eine Illustration der mittels eines Inklinometers gemessenen Abschirmung des Blockes durch die ihn umgebenden Berge. Null entspricht Norden und die Zahlen im Kreis sind die Abschirmungswerte in Grad für das entsprechende Azimuth. Das offene Tal spiegelt sich in den tiefen Werten im Nord-Nordosten wider. Der nach DunNe, Elmore \& MuZIKAR (1999) berechnete Abschirmungsfaktor ist in Tab. 2 dargestellt. 
Table 1: Characteristics of each sample location on the boulder.

Tabelle 1: Charakteristiken jeder Probenlokalität auf dem Block.

\begin{tabular}{|c|c|c|c|c|c|}
\hline & A1 & A2 & A3 & $\mathrm{AU}$ & $\mathrm{AO} / \mathrm{AO} 2$ \\
\hline Strike/dip of sampled surface $\left(^{\circ}\right)$ & $163 / 70$ & $114 / 55$ & $290 / 50$ & $338 / 33$ & horizontal \\
\hline Height of sample location $(\mathrm{cm})$ & 260 & 300 & 350 & 120 & 680 \\
\hline Sample thickness $(\mathrm{cm})$ & $<5$ & $<5$ & $<5$ & $<5$ & $<5$ \\
\hline Quartz vein & & & yes & yes & \\
\hline Snow (thickness $\mathrm{cm} /$ days per year) & $150 / 180 *$ & $20 / 120$ & $150 / 180 *$ & $150 / 180^{*}$ & $30 / 120$ \\
\hline Sample surface $\|$ foliation cleavage & & yes & & & \\
\hline
\end{tabular}

Note: The height of the sample location is above the moraine surface. ${ }^{*}$ Snow height (own observations) is given above the moraine surface, not on the sampled surface of the boulder itself.

most recent and most restricted extent occurred between 1975 and 1991. The other glaciers in the Val d'Arolla show similar moraine systems.

\section{Sample data}

\subsection{Sampling in the field}

Five sides of the boulder were sampled, including bottom and top surfaces (Fig. 2). The aim was to sample in the middle part of each surface to avoid edge effects due to neutron leakage (MASARIK \& WIELER 2003). The rock slabs were taken in the field using dynamite because a large rock sample of 2-3 kg was needed. Small charges were set around a given area and an intact rock plate was blasted free. A large separate of pure quartz is desirable for determining the expected low concentration of ${ }^{10} \mathrm{Be}$ in these samples. Before blasting, strike and dip (Tab. 1), the top position of the sample and the characteristics (e.g. possible erosion, snow and/or sediment cover, quartz veins) were carefully noted. Shielding by surrounding mountains was measured with an inclinometer (Fig. 2c) and the exact position and altitude of the boulder was recorded by GPS. After sampling, photographs for documentation were taken (Fig. 2a and b).

\subsection{Origin of the boulder}

The erratic boulder sampled rests on the crest of the right lateral moraine of the Glacier de Tsijiore Nouve's advance of 1975 to 1991.
From thin section analysis of sample A1, the lithology is a quartz-rich metadiorite, which crops out in much of the glacier catchment area (Fig. 1). This lithology belongs to the Série d'Arolla in the crystalline basement of the Dent Blanche nappe, which is part of the Austroalpine units of the Alps (LABHART 1998; BurRi et al. 1999). The incorporation of the boulder into the glacier system was most likely by falling on the glacier's surface from a collapsing rock cliff, a process, which can be observed today on the rock walls surrounding the steep icefall of the glacier (Fig. 1). Below the icefall, the glacier surface is covered by blocky surface debris, indicating that the production of sediment here mainly occurs by rock fall from the surrounding rock walls. The shape of the boulder itself is not typical of glacial transport as it lacks smooth surfaces and glacial polish. However on a smaller scale, partial smoothing and polishing are visible. This implies a supra- or englacial transport of the boulder. The possibility of being reworked out of older lateral moraine depositions can not be excluded. Its final deposition on the moraine crest occurred during the formation of the moraine. A fine- to coarse-grained gravelly till covers depressions on the boulder top as small and irregular patches (5-6 cm thick). No movement of the boulder is observed since deposition.

\subsection{Sample data}

The elevation of the sampled boulder is $2220 \mathrm{~m}$ a.s.l. and the geographical coordi- 

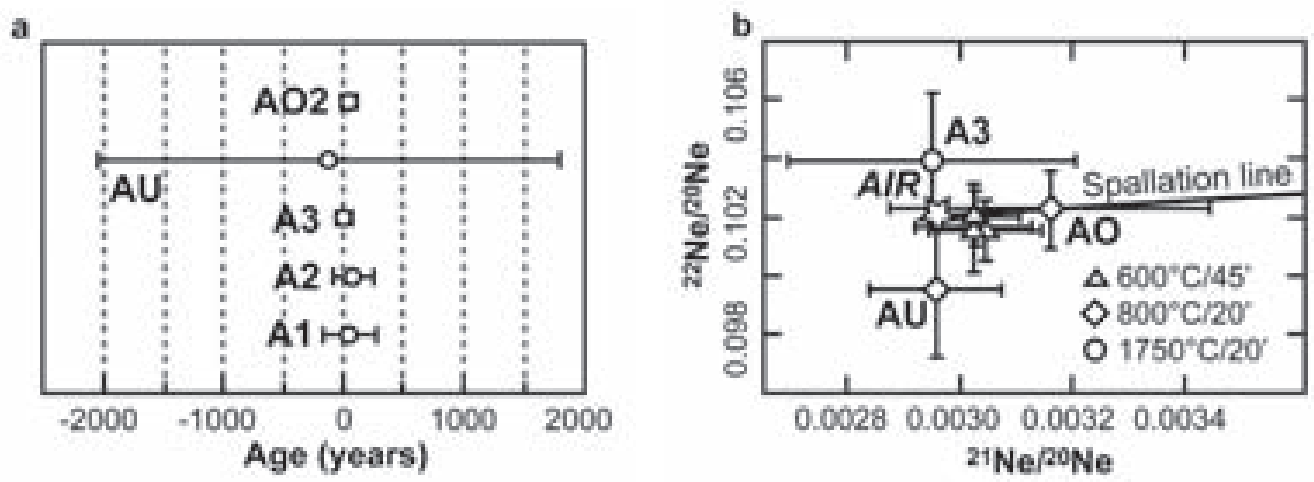

Fig. 3: Diagrams of the cosmogenic nuclides results. a) Diagram of the ${ }^{10} \mathrm{Be}$ results. The black horizontal lines indicate the $1 \sigma$-error. The dot is the calculated mean age. See Tab. 2 for all data. b) Neon 3-isotope diagram of the samples A3, AO and AU. The distinct temperature steps maintained a certain time are indicated by different symbols. Error bars are at $2 \sigma$-levels. After NiEDERMANN (2002), about $90 \%$ of the cosmoge-

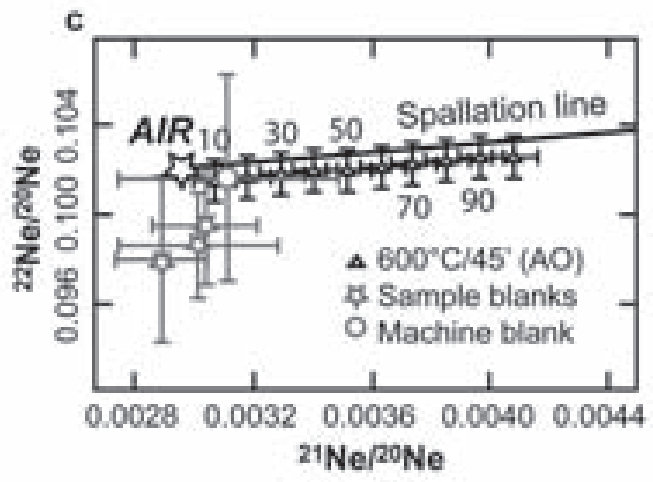
nic ${ }^{21} \mathrm{Ne}$ or more is degassed below $600{ }^{\circ} \mathrm{C}$, and $<1.5 \%$ is left above $800^{\circ} \mathrm{C}$. The last step, $1750{ }^{\circ} \mathrm{C}$, was done to check that all Ne was released and also for the cleaning of the machine. The star displays the Ne air isotopic ratios which are ${ }^{21} \mathrm{Ne} /{ }^{20} \mathrm{Ne}=0.002959$ and ${ }^{22} \mathrm{Ne} /{ }^{20} \mathrm{Ne}=0.102$ (NIEDERMANN 2002, and references therein). All samples have isotopic ratios similar to air within the error bars for the crucial temperature steps. See Tab. 3 for all data. c) The required exposure time for a valid $\mathrm{Ne}$ exposure age, calculated for the Arolla samples. The $600{ }^{\circ} \mathrm{C}$ step of sample AO was used to calculate the required minimal Ne concentrations. The corresponding age is where the error crosses of the sample and of the blanks do not intersect anymore. The large error cross is the machine blank. Ten equals 10,000 years. Accordingly, at least 60,000 years of exposure are required.

Abb. 3: Resultate der gemessenen kosmogenen Nuklide. a) Graphik der ${ }^{10}$ Be Resultate. Die schwarze horizontale Linie gibt den $1 \sigma-$ Fehler an. Der Punkt ist das berechnete mittlere Alter. Für eine Zusammenstellung der Daten siehe Tab. 2. b) Neon 3-Isotopengraphik der Proben A3, AO und AU. Die verschiedenen, jeweils eine bestimmte Zeit beibehaltenen Temperaturschritte sind durch unterschiedliche Symbole gekennzeichnet. Fehlerbalken sind im $2 \sigma$-Level. Etwa $90 \%$ oder mehr des kosmogenen ${ }^{21} \mathrm{Ne}$ entgast unter $600{ }^{\circ} \mathrm{C}$, und $<1.5 \%$ entgast oberhalb $800{ }^{\circ} \mathrm{C}$ (Niedermann 2002). Mit dem letzten Schritt von $1750{ }^{\circ} \mathrm{C}$ wurde kontrolliert, ob alles Ne freigesetzt wurde. Auch wird die Maschine dabei gereinigt. Der Stern symbolisiert das $\mathrm{Ne}$ Verhältnis von Luft von ${ }^{21} \mathrm{Ne} /{ }^{20} \mathrm{Ne}=0.002959$ and ${ }^{22} \mathrm{Ne} /{ }^{20} \mathrm{Ne}=0.102$ (NIEDERMANN 2002, und Referenzen darin). In den ausschlaggebenden Temperaturschritten haben alle Proben innerhalb der Fehlerbalken Isotopenverhältnisse ähnlich wie diejenigen von Luft. Siehe Tab. 3 für alle Daten. c) Die für ein zulässiges Ne Alter notwendige Bestrahlungszeit für die Arolla Proben. Der $600{ }^{\circ} \mathrm{C}$ Temperaturschritt von Probe AO wurde gebraucht, um die notwendigen minimalen Ne Konzentrationen zu berechnen. Das entsprechende Alter ist da, wo die Fehlerkreuze der Probe und der Blindproben sich nicht mehr schneiden. Das große Fehlerkreuz ist die Maschinenblindprobe. Zehn entspricht 10`000 Jahren. Demzufolge sind mindestens $60^{`} 000$ Jahre Bestrahlungszeit notwendig. 
Table 2: Compilation of Be data.

Tabelle 2: Zusammenstellung der Be Daten.

\begin{tabular}{ccccccccc}
\hline \hline Sample & $\begin{array}{c}\text { Production rate } \\
\text { (atoms/g SiO }\end{array}$ *yr) & $\begin{array}{c}\text { Shielding } \\
\text { factor } \\
(\mathrm{Topo}, \mathrm{dip})\end{array}$ & $\begin{array}{c}\text { Quartz } \\
(\mathrm{g})\end{array}$ & $\begin{array}{c}\mathrm{Be} \text { Carrier } \\
(\mathrm{mg})\end{array}$ & $\begin{array}{c}{ }^{10} \mathrm{Be} /{ }^{9} \mathrm{Be} \\
\mathrm{Sample} \\
(1 \mathrm{E}-12)\end{array}$ & $\begin{array}{c}\text { Error } \\
\text { Sample } \\
(\%)\end{array}$ & $\begin{array}{c}{ }^{10} \mathrm{Be} * 10^{4} \\
\left(\text { atoms/g } \mathrm{SiO}_{2}\right)\end{array}$ & $\begin{array}{c}\text { Age } \\
\text { (years })\end{array}$ \\
\hline $\mathrm{A} 1$ & 20.86 & 0.70 & 47.15 & 0.4013 & 0.014 & 54.1 & $0.105 \pm 0.456$ & $51 \pm 220$ \\
$\mathrm{~A} 2$ & 24.91 & 0.84 & 45.40 & 0.4034 & 0.016 & 44.2 & $0.198 \pm 0.433$ & $75 \pm 164$ \\
$\mathrm{~A} 3$ & 25.85 & 0.87 & 91.48 & 0.4026 & 0.013 & 40.4 & $0.013 \pm 0.166$ & $5 \pm 60$ \\
$\mathrm{AU}$ & 1.32 & 0.04 & 62.53 & 0.4042 & 0.012 & 45.4 & $-0.015 \pm 0.255$ & $-110 \pm 1821$ \\
$\mathrm{AO} 2$ & 28.75 & 0.97 & 70.73 & 0.4044 & 0.016 & 28.9 & $0.128 \pm 0.194$ & $41 \pm 63$ \\
\hline
\end{tabular}

Note: The AMS measurement uncertainty for sample and blank are at the $1 \sigma$-level. The error of the used standard $( \pm 2.5 \%)$ is not included. A weighted mean blank of ${ }^{10} \mathrm{Be} /{ }^{9} \mathrm{Be}=0.012 * 10^{-12}$ with an error of $18.3 \%$ was taken for the subtraction step. A sea level, high latitude production rate of 5.1 atoms $/ \mathrm{g} \mathrm{SiO}_{2} * \mathrm{yr}$ ( $\mathrm{STONE}$ 2000) was used.

nates are $\mathrm{E} 7^{\circ} 28^{\prime} 21.16^{\prime \prime}$ and $\mathrm{N} 46^{\circ} 1$ ' $3.08^{\prime \prime}$ (=602626/096220 in the Swiss grid). Its height is $6.80 \mathrm{~m}$, the length $9.50 \mathrm{~m}$ and the width $4.10 \mathrm{~m}$. Based on thin section analysis, the rock consists of $50 \%$ quartz, occurring as dynamically recrystallized fine-grained crystals alongside quartz porphyroclasts. Quartz-rich layers alternate with mica layers. Accessory minerals including apatite, zircon and opaque minerals are also identifiable (BURRI et al. 1999). In addition, a reaction with $\mathrm{HCl}$ during the first quartz purification step points to the presence of calcite in the rock.

\section{Methods}

\subsection{Production rate systematics and age calculation}

Cosmogenic nuclides are produced in the upper surface of a rock by nuclear reactions induced by cosmic rays (Lal \& Peters 1967). $\mathrm{P}_{0}$ (atoms/yr*g SiO$)_{2}$ ) is the isotope production rate valid for the exposure time and normalized to sea-level, high geomagnetic latitude $\left(\geq 60^{\circ}\right)$ and open sky conditions (GossE \& Phillips 2001). A sea level, high latitude ${ }^{10} \mathrm{Be}$ production rate of 5.1 atoms $/ \mathrm{g} \mathrm{SiO}_{2} * \mathrm{yr}$ (STONE $2000)$ and a sea level, high latitude ${ }^{21} \mathrm{Ne}$ production rate of $20.3 \pm 3.7$ atoms $/ \mathrm{g} \mathrm{SiO}_{2} * \mathrm{yr}$ (Niedermann 2000) were used in this study.
Latitude (geographic) and altitude scaling of $\mathrm{P}_{0}$ follows Stone (2000). As sample thickness did not exceed $5 \mathrm{~cm}$, it was not necessary to correct $\mathrm{P}_{0}$ for thickness (MASARIK \& REEDy 1995). Corrections were also not made for magnetic field changes, as the exposure time of the boulder is negligible compared to the time scales of magnetic field fluctuations (MASARIK et al. 2001).

The surrounding mountain ranges with an average elevation of ca. $3000 \mathrm{~m}$ a.s.l. partially shield the boulder from the incoming cosmic ray flux. Therefore, only a fraction of the total incoming flux is available for the production of the cosmogenic nuclides. The circle in Fig. 2c illustrates the measured shielding values for sample AO/AO2 in degrees. The dip of the sampled surfaces of the other samples reduces their horizon and thus production rates of the cosmogenic nuclides to even lower values (Tab. 2). To the northeast, the "open valley" allows a higher amount of cosmic rays to pass while, to the south, the Pigne d'Arolla blocks the cosmic ray flux. The bottom-boulder sample AU has the lowest production rate as a result of the corrections for the overall shielding by the boulder itself. Shielding corrections were calculated following Dunne, Elmore \& Muzikar (1999). For all samples, no correction due to vegetation cover was necessary. We observed snow on the moraine in winter of about $1.5 \mathrm{~m}$ thickness. Winter snow cover on the surfaces of the 
Table 3: Compilation of $\mathrm{Ne}$ data.

Tabelle 3: Zusammenstellung der Ne Daten.

\begin{tabular}{lllll}
\hline Sample & $\begin{array}{l}\text { Step } \\
\left({ }^{\circ} \mathrm{C}, \min \right)\end{array}$ & $\begin{array}{l}{ }^{20} \mathrm{Ne} \\
\left(10^{9} \text { atoms } / \mathrm{g}\right)\end{array}$ & $\begin{array}{l}{ }^{21} \mathrm{Ne} /{ }^{20} \mathrm{Ne} \\
\left(10^{-3}\right)\end{array}$ & ${ }^{22} \mathrm{Ne} /{ }^{20} \mathrm{Ne}$ \\
\hline \multirow{2}{*}{$\mathrm{A} 3$} & 600,45 & $8.43 \pm 0.227$ & $3.05 \pm 0.100$ & $0.10 \pm 0.001$ \\
& 1750,20 & $1.42 \pm 0.047$ & $2.95 \pm 0.255$ & $0.10 \pm 0.002$ \\
\hline \multirow{2}{*}{ AO } & 600,45 & $10.40 \pm 0.284$ & $3.03 \pm 0.078$ & $0.10 \pm 0.001$ \\
& 800,20 & $1.43 \pm 0.048$ & $3.16 \pm 0.284$ & $0.10 \pm 0.001$ \\
& 1750,20 & $1.05 \pm 0.032$ & $14.2 \pm 0.524$ & $0.11 \pm 0.003$ \\
\hline \multirow{2}{*}{ AU } & 600,45 & $7.65 \pm 0.203$ & $3.03 \pm 0.104$ & $0.10 \pm 0.002$ \\
& 800,20 & $1.70 \pm 0.046$ & $2.96 \pm 0.119$ & $0.10 \pm 0.002$ \\
\hline \hline
\end{tabular}

Note: Errors are at the $2 \sigma$-level. Included are uncertainties in mass discrimination and sensitivity while uncertainties of calibration gas concentrations are not included. They are expected to be smaller than $3 \%$. About $90 \%$ of the cosmogenic ${ }^{21} \mathrm{Ne}$ or more is degassed below $600{ }^{\circ} \mathrm{C}$ (NIEDERMAnN 2002). For sample A3, $41.77 \mathrm{mg}$ of an ultra-pure quartz separate was used for the step-wise heating procedure following NIEDERMANN, GRAF \& Marti (1993) and Niedermann (2002). For sample AO, $46.66 \mathrm{mg}$ quartz was loaded onto the noble gas mass spectrometer and for $\mathrm{AU} 43.66 \mathrm{mg}$. In Fig. $3 \mathrm{~b}$, the ${ }^{21} \mathrm{Ne} /{ }^{20} \mathrm{Ne}$ and ${ }^{22} \mathrm{Ne} /{ }^{20} \mathrm{Ne}$ ratios of all temperature steps are plotted.

boulder is $30 \mathrm{~cm}$ or less and on the steep sides of the boulder no snow remains. All samples experience less than $30 \mathrm{~cm}$ of snow cover (in the case of sample AU location height is $1.20 \mathrm{~m}$ above moraine surface while snow cover on the moraine is $1.50 \mathrm{~m}$ ) (Tab. 1). After the model of MASARIK \& REEDY (1995), the cosmogenic production rate on the boulder surface is not affected until snow cover exceeds $40 \mathrm{~cm}$ (assuming a snow density of $0.3 \mathrm{~g} / \mathrm{cm}^{3}$ ). Therefore, no correction for snow cover was performed.

The ages were calculated using the equation in Gosse \& Phillips (2001), assuming no erosion.

\subsection{Laboratory analysis}

For extracting ${ }^{10} \mathrm{Be}$ from dissolved quartz, the methods described in Ochs \& Ivy-Ochs (1997) were followed. The pure quartz mineral separate was produced by selective chemical dissolution using hydrofluoric acid, following the procedure of KoHL \& Nishizzumi (1992). Laboratory work was carried out at the Institute of Geological Sciences at the University of Bern. Measurements of ${ }^{10} \mathrm{Be} /{ }^{9} \mathrm{Be}$ ratios of the samples and the necessary blanks were done by accele- rator mass spectrometry at the ETH/PSI tandem facility in Zurich.

Pure quartz was handpicked for $\mathrm{Ne}$ analysis. Noble gas concentrations were measured with a $90^{\circ}$ sector field static noble gas mass spectrometer at the noble gas laboratory at ETH Zurich (BEYERLE et al. 2000). This spectrometer features a modified Baur/Signer ion source equipped with a compressor that enhances the sensitivity for helium and neon by two orders of magnitude (BAUR 1999). We applied stepwise heating to enrich the cosmogenic neon fraction in the low-temperature steps.

\section{Results and discussion}

\subsection{Samples}

The ${ }^{10} \mathrm{Be}$ ages are shown in Fig. 3a and Tab.2. All ages are zero within uncertainties. Their relatively high error is due to the low ${ }^{10} \mathrm{Be}$ concentrations in the samples, which are similar to the measured blank values. The mean age of sample AU is negative and only the upper limit of the age is realistic. This is due to the subtraction of the mean blank value, which has 
a higher ${ }^{10} \mathrm{Be} /{ }^{9} \mathrm{Be}$ ratio of $0.012 * 10^{-12}$ than the sample ratio. The high shielding effect by the surrounding mountains and the boulder itself and the consequential small production rate also contribute to the particularly low ${ }^{10} \mathrm{Be}$ concentration of this bottom sample.

The ${ }^{21} \mathrm{Ne} /{ }^{20} \mathrm{Ne}$ and the ${ }^{22} \mathrm{Ne} /{ }^{20} \mathrm{Ne}$ ratios of the samples A3, AO and AU are similar to air ratios (Fig. 3b, Tab. 3). Accordingly, no excess of cosmogenic ${ }^{21} \mathrm{Ne}$ and ${ }^{22} \mathrm{Ne}$, which would have been produced in a previous period of exposure, were detected. No differences between the $\mathrm{Ne}$ isotope ratios of the three samples are observed.

\subsection{General context}

A first test for inherited nuclides was performed by DAvis et al. in 1999. They analyzed eight samples collected from boulders, cobbles and recently uncovered bedrock from the area left after the Tumbling Glacier, Baffin Island, retreated from its 1976 and 1959 limit. Most samples of this Arctic fjord environment yielded ${ }^{26} \mathrm{Al}$ nuclide concentrations equivalent to less than 1000 years of surface exposure; the ${ }^{10} \mathrm{Be}$ measurements were within 2 sigma of their blank value. DAvis et al. (1999) concluded that glacial erosion must have been sufficient to remove the nuclide signal gained in a previous period of exposure, e.g. during an interglacial or interstadial. In an Alpine environment with a higher relief, data from the Nägelisgrätli in the Grimsel region in Central Switzerland show that nuclide inheritance is also negligible (KeLLy et al. 2006). Based on these data and on the fact that at $3 \mathrm{~m}$ depth in the rock production of nuclides is only a few percent of the value at the surface (LAL 1991), the authors concluded that at least $3 \mathrm{~m}$ of rock was removed during the Last Glacial Maximum (LGM) and that therefore nuclide inheritance originating from exposure prior to the LGM in the Alps is low (Ivy-Ochs, Kerschner \& Schlüchter 2007).

Sample AO2 of our study would require at least 300 years of pre-exposure to yield a ${ }^{10} \mathrm{Be} /{ }^{9} \mathrm{Be}$ ratio clearly outside the uncertainties of the blank value. For the $\mathrm{Ne}$ data, at least 60,000 years of exposure to cosmic rays would be required to build up a minimal detectable amount for sample AO (Fig. 3c). Assuming that the clock has been "zeroed" by LGM glacial erosion, nuclide inheritance could have only accumulated during low glacial stands following the LGM. In case of the Ne data, time since the LGM was too short to build up a detectable amount of cosmogenic Ne. For ${ }^{10} \mathrm{Be}$, considering the Holocene glacial history of this region and of the Alps in general (SCHNEEBELI \& RöTHLisberger 1976; Jörin, Stocker \& Schlüchter 2006), the required time span of at least 300 years of phases with a shorter glacial extent than today would easily be reached. Therefore, it can be concluded that the ${ }^{10} \mathrm{Be}$ concentration of the boulder was zero when it was incorporated into the glacier system.

\section{Conclusion}

The aim of this work was to test a boulder for inherited nuclides from previous periods of exposure. We are aware that we are dealing with one single boulder only; however, in a first approach a multi-isotope and multi-surface study is an absolutely necessary step in evaluating the case of pre-exposure of erratic boulder surfaces. As the known exposure time of the block is about 12 years, the nuclide concentration built up since exposure should be undetectable if no previous exposure of the surfaces has occurred. The ${ }^{10} \mathrm{Be}$ and the ${ }^{21} \mathrm{Ne}$ results demonstrate that none of the sides of the boulder that we sampled experienced pre-exposure. The build-up of the cosmogenic nuclides started with its deposition on the moraine crest, as all of the samples show zero exposure ages within error. The uncertainties are relatively high due to the high error in the measuring step which again results from the low ${ }^{10} \mathrm{Be}$ concentration in the samples. The several hundred years of pre-exposure required for building up a minimal detectable amount of ${ }^{10} \mathrm{Be}$ would be easily reached in geological time scales, as well as the 60,000 years required for ${ }^{21} \mathrm{Ne}$. This implies that the concentration of cosmogenic nuclides in the boulder was zero by the time of its incorporation in the glacier sys- 
tem; possible subsequent gain of cosmogenic nuclides is in the undetectable range or was immediately lost during transport.

\section{Acknowledgements}

Many thanks go to Diego Sanz and Ueli Jörin for their help collecting the samples. The laboratory work was done at the Institute of Geological Sciences at the University of Bern. The measuring of the ${ }^{10} \mathrm{Be}$ samples was performed by Peter W. Kubik at the Zurich AMS Facility jointly operated by the Swiss Federal Institute of Technology, Zurich and Paul Scherrer Institute, Villigen, Switzerland. The manuscript was greatly improved by comments from Joerg $\mathrm{M}$. Schaefer, Vincent Rinterknecht, Rainer Wieler, Sven Lukas and Peter W. Kubik. We thank the Swiss National Science Foundation for supporting this project.

\section{References}

Aвbühl, L.M., Dadic, R., Fischer, L., Müller, B. \& ZAHNO, C. (2002): Geomorphologische Kartierarbeit in Arolla (VS). - Unpublished geomorphologic map; ETH Zürich.

Baur, H. (1999): A Noble-Gas Mass Spectrometer compressor source with two orders of magnitude improvement in sensitivity. - EOS Transactions, 80: Supplement.

Beyerle, U., Aeschbach-Hertig, W., Imboden, D.M., Baur, H., Graf, T. \& Kipfer, R. (2000): A mass spectrometric system for the analysis of noble gases and tritium from water samples. - Environmental Science \& Technology, 34/10: 20422050.

Brook, E.J., Brown, E.T., Kurz, M.D., Ackert, R.P., Raisbeck, G.M. \& Yiou, F. (1995): Constraints on age, erosion and uplift of Neogene glacial deposits in the Transantarctic Mountains using in situ cosmogenic ${ }^{10} \mathrm{Be}$ and ${ }^{26} \mathrm{Al}$. - Geology, 23: 1063-1066.

Brown, E.T., Edmond, J.M., Raisbeck, G.M., Yiou, F., Kurz, M.D. \& BrooK, E.J. (1991): Examination of surface exposure ages of Antarctic moraines using in situ produced ${ }^{10} \mathrm{Be}$ and ${ }^{26} \mathrm{Al}$. - Geochimica et Cosmochimica Acta, 55: 2269-2283.

Burri, M., dal Paz, G.V., della Valle, G., Gouffon, Y. \& Guermani, A. (1999): Atlas géologique de la Suisse, feuille 101. 1346 Chanrion avec partie nord de la feuille 1366 Mont Vélan. Notice explicative. -79 p.; Bern (Federal Office of Topography).

Davis, P.T., Bierman, P.R., Marsella, K.A., Caffee, M.W. \& Southon, J.R. (1999): Cosmogenic analysis of glacial terrains in the eastern Canadian Arctic: a test for inherited nuclides and the effectiveness of glacial erosion. - Annals of Glaciology, 28: 181-188.

Dunne, J., Elmore, D. \& MuziKar, P. (1999): Scaling factors for the rates of production of cosmogenic nuclides for geometric shielding and attenuation at depth on sloped surfaces. - Geomorphology, 27: 3-11.

Gosse, J.C. \& Phillips, F.M. (2001): Terrestrial in situ cosmogenic nuclides: theory and application. Quaternary Science Reviews, 20: 1475-1560.

Graf, T., Kohl, C.P., Marti, K. \& Nishilzumi, K. (1991): Cosmic-ray produced neon in Antarctic rocks. - Geophysical Research Letters, 18: 203206.

Ivy-Ochs, S., Kerschner H. \& Schlüchter C. (2007): Cosmogenic nuclides and the dating of Lateglacial and Early Holocene glacier variations: The Alpine perspective. - Quaternary International, 164-165: 53-63.

Jörin, U.E., Stocker, T.F. \& SCHLÜChter, C. (2006): Multicentury glacier fluctuations in the Swiss Alps during the Holocene. - The Holocene, 16: 697-704.

Kelly, M.A., Ivy-Ochs, S., KubIK, P.W., von Blanckenburg, F. \& SChlÜChter, C. (2006): Exposure ages of glacial erosional features in the Grimsel Pass region, central Swiss Alps. Boreas, 35: 634-643.

Kohl, C.P. \& Nishizumi, K. (1992): Chemical isolation of quartz for measurement of in-situ produced cosmogenic nuclides. - Geochimica et Cosmochimica Acta, 56: 3583-3587.

LABHART, T.P. (1998): Geologie der Schweiz. - 211 p.; Thun (Ott Verlag).

LAL, D. (1991): Cosmic ray labeling of erosion surfaces: in situ nuclide production rates and erosion models. - Earth and Planetary Science Letters, 104: 424-439.

LAL, D. \& Peters, B. (1967): Cosmic ray produced radioactivity on the earth. - Handbuch der Physik, Vol. 46/2: 551-612; Berlin (Springer).

MAsarik, J. \& ReEdy, R.C. (1995): Terrestrial cosmogenic-nuclide production systematics calculated from numerical simulations. - Earth and Planetary Science Letters, 136: 381-395. 
Masarik, J. \& Wieler, R. (2003): Production rates of cosmogenic nuclides in boulders. - Earth and Planetary Science Letters, 216: 201-208.

Masarik, J., Frank, M., Schäfer, J.M. \& Wieler, R. (2001): Correction of in situ cosmogenic nuclide production rates for geomagnetic field intensity variations during the past 800,000 years. - Geochimica et Cosmochimica Acta, 65/17: 29953003.

NiedERMANN, S. (2002): Cosmic-ray-produced noble gases in terrestrial rocks: dating tools for surface processes. - Reviews in Mineralogy and Geochemistry, 47: 731-784.

Niedermann, S. (2000): The ${ }^{21} \mathrm{Ne}$ production rate in quartz revisited. - Earth and Planetary Science Letters, 183: 361-364.

Niedermann, S., Graf, T. \& Marti, K. (1993): Mass spectrometric identification of cosmic-ray-produced neon in terrestrial rocks with multiple neon components. - Earth and Planetary Science Letters, 118: 65-73.
Ochs, M. \& Ivy-Ochs, S. (1997): The chemical behavior of $\mathrm{Be}, \mathrm{Al}, \mathrm{Fe}, \mathrm{Ca}$ and $\mathrm{Mg}$ during AMS target preparation from terrestrial silicates modeled with chemical speciation calculations. - Nuclear Instruments and Methods in Physics Research, B123: 235-240.

Schneebeli, W. \& Röthlisberger, F. (1976): 8000 Jahre Walliser Gletschergeschichte. Ein Beitrag zur Erforschung des Klimaverlaufs in der Nacheiszeit. - 156 p.; Bern (Schweizer Alpen Club (SAC)).

Stone, J.O. (2000): Air pressure and cosmogenic isotope production. - Journal of Geophysical Research, 105: 23,753-23,759. 